\title{
Quality management and quality practice: Perspectives on their history and their future
}

\author{
N. I. Fisher ${ }^{1,2, *, \dagger}$ and V. N. Nair ${ }^{3}$ \\ ${ }^{1}$ School of Mathematics and Statistics, University of Sydney, F07, NSW 2006, Australia \\ ${ }^{2}$ ValueMetrics Australia, Australia \\ ${ }^{3}$ Departments of Statistics and Industrial Operations and Engineering, University of Michigan, \\ 453 West Hall, Ann Arbor, MI 48109-1092, U.S.A.
}

\begin{abstract}
SUMMARY
The purpose of this article and a companion article is to explore a number of topics in Statistics in Business and Industry. This article sketches the history of Quality Management, from its emergence in the late 19th and early 20th centuries through to the present day. Particular emphasis is placed on activities in Japan immediately following the end of the Second World War, and subsequent developments elsewhere in the world. We draw a careful distinction between Quality Management and various methodologies that aid in its implementation, such as Six Sigma. In the words of one management practitioner, Norbert Vogel, 'TQM in its broadest sense examines all aspects of management and the alternative methodologies being promoted are merely sub-sets of what should be an integrated management system.' The article concludes with some speculative thoughts about the future of Quality Management from a statistician's point of view. Copyright (c) 2009 John Wiley \& Sons, Ltd.
\end{abstract}

Received 30 June 2008; Revised 5 December 2008; Accepted 5 December 2008

KEY WORDS: post-war reconstruction in Japan; quality control; Six Sigma; TQM

\section{INTRODUCTION}

In this and in a companion article [1] we explore, to varying depths, a number of topics in Statistics in Business and Industry. For obvious reasons, we have focused on topics with which we have some familiarity. The scope of Business and Industrial Statistics is now far too broad for any two people to provide well-informed in-depth commentary across the complete spectrum of activity. This first

\footnotetext{
${ }^{*}$ Correspondence to: N. I. Fisher, School of Mathematics and Statistics, F07, University of Sydney, NSW 2006, Australia.

${ }^{\dagger}$ E-mail: nickf@maths.usyd.edu.au

Contract/grant sponsor: ValueMetrics Australia

Contract/grant sponsor: NSF-DMS; contract/grant number: 0505535
}

Copyright (C) 2009 John Wiley \& Sons, Ltd. 
article looks at the area of Quality Management, its origins and evolution, with particular reference to statistical aspects. The second article covers developments in methodology and applications.

Section 2 of this article sketches the history of Quality Management, starting with its emergence in the late 19th and early 20th centuries in Europe and the U.S.A. leading up to Walter Shewhart's landmark work on statistical process control charts. We then provide a more detailed discussion of activities in Japan immediately following the end of the Second World War. From there, we look at the emergence of the modern 'Quality movement' which dates from the late 1970s. Section 3 provides some speculative thoughts about the future of Quality Management from a statistician's point of view and Section 4 contains some concluding remarks.

In a narrow sense-and in its original centuries'-old sense- 'Quality' equated to providing something that met the requirements of the person acquiring the product or receiving the service. The articles in Juran's edited work [2] on 'A History of Managing for Quality' relate mainly to this sense of the word. In its widest sense, as has been developing since the late 19th century and as is the focus of this article, 'Quality' refers to the way an enterprise goes about its business, inspired by a theory that acts as a guiding principle for behaviour and informed by the knowledge and knowhow needed to make it occur.

Little is recorded about how, pre-Shewhart, statistical methods were used to assure (narrowsense) Quality. Post-Shewhart, of course, this was resolved. Indeed, it is hard to understand today how one can achieve Quality in an efficient way without resorting to control charts and other associated statistical methods to assure process capability. Yet, as we shall see, one of the leading Quality Awards still does not have a prominent role for Data and Analysis in its framework, after some two decades of existence. And at the opposite extreme, in the early years of post-war reconstruction in Japan one group held the belief that Statistical Quality Control was effectively the sole requirement for assuring Quality, whereas without a culture of 'Quality Management'—or 'Total Quality Control', or 'Total Quality Management'-in other words, without an appreciation of the need for everything to be done in accordance with certain principles of good management practice, assuring 'narrow-sense' Quality is not sustainable in the long term. In the following section we expand on these considerations.

\section{HISTORICAL PERSPECTIVES}

This section draws heavily on the work of the two leading scholars in the area: Myron Tribus, who has studied historical developments very broadly; and Kenneth Hopper, who has devoted a lifetime to studying what happened in post-war Japan, and subsequently in the U.S.A. There is so little awareness among many statisticians of what took place that we have provided a certain amount of detail here. (See, Fisher [3] for a more detailed study of the period 1945-1950 in post-war Japan.)

\subsection{The beginnings}

Aspects of managing to assure product quality can be traced back to hundreds, indeed thousands of years (e.g. Juran [2]). By the latter part of the 13th century, medieval craftsmen had begin to organize themselves in guilds that developed formal procedures for product and service quality and enforced them strictly. Goods were regularly inspected, and high quality goods were marked with special symbols. This approach was followed in manufacturing in the industrialized world until the Industrial Revolution in the early 19th century. Mass production after the Industrial Revolution 
led to the factory system, where craftsmen became factory workers, and their work was grouped into specialized tasks. Inspection (mostly end of line) was used to make sure that the products shipped to customers were of reasonable quality.

This model was further expanded in the United States in the latter part of the 19th century under the management system developed by Frederick Winston Taylor (1856-1915), whose goal was significant improvement of productivity; see e.g. Taylor [4]. This resulted in further diminishing the role of craftsmen and institutionalization of inspection departments (see, e.g. Sarasohn [5] and Juran [2, Chapter 17]).

Myron Tribus has traced formalized good management practice at least to the beginnings of the 20th century. In March 2000, he distributed the following announcement about a conference to be held in the following year in Zlin (Czech Republic), which we reproduce in full as it is not publicly available:

\section{First International Conference on \\ BATA SYSTEM OF MANAGEMENT \\ Its Impacts on Management and Entrepreneurship \\ In the Third Millennium}

The Bata Foundation and the Faculty of Management and Economics in Zlin, together with local and international sponsors, are proud to announce that on May 16 through 18, 2001, there will be an international conference in Zlin. We aim to bring to the attention of managers, management consultants and researchers the contributions to management theory and practice developed by Tomas Bata and his associates. Tomas Bata and Bata-System of management are not well known today even though their success and heritage value are undisputed and awe-inspiring in the New Economy. T. Bata died in 1932 in a plane crash. By the time of his death he had introduced fundamental changes in management philosophy and techniques. Many of Bata approaches have been 'discovered' during the last 20 years by the Western World as part of what has become known as the 'Quality Revolution'. Quality management was practiced by the Bata enterprises since before the World War I, through 1920s, 1930s and 1940s, well before the 'gurus of quality' even started thinking about the subject. Japanese visitors came to Zlin to learn about the Bata system well before the World War II. In addition, Bata executives traveled to Japan in 1937 and predicted the industrial rise of Japan at that time.

(See Appendix A for more specific information about the 'Quality Management' aspects of Bata's work.)

The birth of modern statistical quality control is widely attributed to the work of Walter Shewhart at Western Electric:

By the turn of the century, Western Electric had trained individuals as inspectors to assure specification and quality standards, in order to avoid sending bad products to the customer. In the 1920s, Western Electric's Dr Walter Shewhart took manufacturing quality to the next level-employing statistical techniques to control processes to minimize defective output. When Dr Shewhart joined the Inspection Engineering Department at Hawthorne in 1918, industrial quality was limited to inspecting finished products and removing defective items. All that changed in May 1924. Dr Shewhart's boss, George Edwards, recalled: 'Dr Shewhart prepared a little memorandum only about a page in length. About a third of that page was given over to a simple diagram which we would all recognize today as a schematic control chart. That diagram, and the short text that preceded and followed it, set forth all of the essential 
principles and considerations which are involved in what we know today as process quality control'. Mr Edwards had observed the birth of the modem scientific study of process control. That same year, Dr Shewhart created the first statistical control charts of manufacturing processes, which involved statistical sampling procedures. Shewhart published his findings in a 1931 book, Economic Control of Quality of Manufactured Product. http://www.porticus.org/bell/westernelectric_history.html

Shewhart characterized the sources of variation in a process into two groups: (a) common cause or chance variation; and (b) special cause or assignable variation. The control chart was developed to monitor the underlying variation and determine when the process exhibits special cause variation (see e.g. Shewhart [6]). Shewhart's idea still forms the basis of statistical process control as practised in industry, although there are many enhancements to the basic Shewhart charts (Appendix C, Item 1).

Another related development was the work on acceptance sampling by Harold Dodge and Harry Romig, also at Bell Telephone Laboratories, starting in the 1920s. The American Society for Quality quotes Dodge as saying:

It all goes back to the beginnings of statistical quality control in 1924. Our work in cooperation with shop engineers was influenced heavily by great pressures to save money and to make the quality control methods simple and easy to use.

http://www.asq.org/about-asq/who-we-are/bio_dodge.html

This led to the development and use of scientific sampling plans for inspection (e.g. Dodge and Romig [7]), and the notion of consumer's and producer's risks. See Dodge [8] for a historical account. These methods were extensively used during World War II in weapons manufacturing.

We now turn to the more general evolution of formalized good management because it provides insight into how statisticians have-or have not—been involved in the past, and how they might be involved in the future. The setting for developments was Japan, immediately after the Second World War.

\subsection{Quality Management in post-war Japan}

The next major stop appears to be post-war Japan at the end of 1945, where General Douglas MacArthur (Supreme Commander of the Allied Powers-SCAP) commenced the process of postwar reconstruction. Key sources of information (cf. Appendix C, Item 2) about this period include

- 'How Quality First Came to Japan', a videotape made in 1988 by Myron Tribus of an interview he conducted with Homer Sarasohn. (At the time of writing, this interview is being transferred to digital format, with the prospect that it will become available via the Web.)

- Sarasohn's own account of this period, presented at a conference in Sydney, April 1997 (Sarasohn [9]).

- Extensive research by Kenneth Hopper, much of which is summarized or referenced in a recent book, The Puritan Gift (Hopper and Hopper [10]) written with his brother William.

- Chapter 6 (Children of the Occupation) in John Butman's authorized biography of Joseph Juran (Butman [11]).

- The web sites http://www.honoringhomer.net/ and http://www.puritangift.com/ (the latter being resources made available by Kenneth Hopper). 
So, who was Homer Sarasohn, and what was his involvement in post-war Japan, as it bears on the topic?

Sarasohn was a radio engineer who had been invalided out of the paratroops during the war, proceeded to work on Project Cadillac (to do with radar) at MIT, and then subsequently put his radar knowledge to civilian use in the development of transcontinental microwave transmitters. He was summoned to Japan early in 1946, charged with establishing a communications industry in Japan. MacArthur told Sarasohn that he had three requirements (Sarasohn [9]):

(i) Supply domestic radio receivers to the Japanese people as an immediate communications medium in support of SCAP's Civil Information and Education Section. (Army transmitters would be used as the broadcast source.)

(ii) Meet the needs of the Occupation Forces (and also domestic users) for a reliable nation-wide telecommunications facility.

(iii) Assist the Japanese communications equipment manufacturing industry to become a major contributor for a revived national economy.

The issues confronting Sarasohn-no manufacturing capability, no senior management available, no companies extant-have been recounted briefly by Sarasohn (Sarasohn and Protzman [12]) and more extensively in the taped interview with Myron Tribus. According to Sarasohn's 1997 account, he devoted his efforts to the first of these issues, with a colleague (Wilbur Magill, from AT\&T's Hawthorne plant) working on the second. In Sarasohn's words, 'I did not worry too much about the third task. If we were successful in accomplishing the first two, the other would take care of itself'. (In fact, Sarasohn related with some pride in the interview that a measure of success of their efforts was that this was the first Japanese industry to be taxed, after the war.)

The events of the next 4 years provided the basis for a remarkable transformation of Japanese industry. It is also a period clouded by contention: who actually taught what to whom, how and when did this occur, and so forth? Fisher [3] has sought to separate the factual information from the speculative. Our 'best estimate' of what actually happened is summarized in Table I (see Fisher, op. cit. for references).

Sarasohn arrived to a scene of devastation - the whole industrial strip from Tokyo to Yokohama flattened by bombing, no equipment, virtually no companies functioning, all top management dead or in jail. As Sarasohn describes the situation:

There were physical problems, and there were cultural problems. Among the more pressing physical problems were these. Factory sites had to be cleared of rubble so that shacks could be put up to house production machinery and workers. Machinery had to be installed, repaired and refurbished. Workers had to be recruited and trained. Supplies and raw materials had to be located and brought in. Supervisors and managers had to be chosen, some almost at random, and put in place. Most of them were strangers to their jobs. They came with little or no managerial experience. In their previous positions, they essentially had been conduits for the flow of instructions between their superiors on one side, and the workers on the other. They were not business planners. They were not leaders nor decision makers. They were more accustomed to following orders, rather than giving direction. They had little understanding of industrial strategy or policy. They were confused, lacking in self-confidence and uncomfortable in the positions into which they had been force-fit. They had to be instructed on a day-to-day basis how to set up, run, and manage a mass production system. And, that is what we in CCS did (Sarasohn [9]). 
In 1948, Charles Protzman arrived to work with Sarasohn. They came to the view that the company leaders would need to be taught about industrial management. The initial CCS (Civil Communications Section) Management Seminars were presented in late 1949 and early 1950, based on a manual they prepared on The Principles of Industrial Management [12]. The section on Quality Control comprises 63 pages in original version, pp 102-124 in the e-version, with a brief

Table I. Overview of the evolution of Quality Management in Japan, 1945-1954.

\begin{tabular}{|c|c|}
\hline Date & Event and people \\
\hline 2 Sept 1945 & Japan's formal surrender \\
\hline Sep/Oct 1945 & $\begin{array}{l}\text { SCAP [Supreme Commander for Allied Powers] organization } \\
\text { chart shows existence of CCS (Civil Communications Section) }\end{array}$ \\
\hline Mar 1946 & $\begin{array}{l}\text { Homer Sarasohn brought to Japan by General Douglas } \\
\text { MacArthur. Civil Communications Section (CCS) Unit set up. }\end{array}$ \\
\hline May 1946 & $\begin{array}{l}\text { Formation of JUSE (Union of Japanese Scientists and } \\
\text { Engineers); founding chairman Ichirô Ishikawa }\end{array}$ \\
\hline 1947 & $\begin{array}{l}\text { W Edwards Deming visits Japan to advise on survey methods } \\
\text { to assist SCAP in understanding the local demographics relative } \\
\text { to food distribution, health statistics, social services, etc. }\end{array}$ \\
\hline Mar 1948 & JUSE establishes committee to study SQC \\
\hline Nov 1948 & $\begin{array}{l}\text { Charles Protzman arrives in Japan to join CCS, tasked with } \\
\text { advising the Japanese on rebuilding their communications } \\
\text { system }\end{array}$ \\
\hline 1949 & $\begin{array}{l}\text { Sarasohn and Protzman develop CCS Management Seminar, } \\
\text { starting with survey of the needs of the companies. Then they } \\
\text { go off to a hotel in Osaka for one month, sit down in separate } \\
\text { rooms, and write a manual on The Principles of Industrial } \\
\text { Management [12]. The section on Quality Control comprises } 63 \\
\text { pages in original version, } p p 102-124 \text { in the } 1998 \text { e-version, } \\
\text { with a brief discussion of control charts. The term 'Cost of } \\
\text { Quality' appears here. Economic and Scientific Section (ESS) } \\
\text { of SCAP, which was essentially responsible for all Japanese } \\
\text { industry except communications, opposes Seminar on grounds } \\
\text { that 'we should not teach the Japanese about progressive } \\
\text { management; there was a competitive danger in raising the } \\
\text { industry's productivity level too high; we might make it more } \\
\text { difficult for American companies to get a commercial foothold } \\
\text { in Japan.' [9]. After presentations by ESS officer and by } \\
\text { Sarasohn to MacArthur, MacArthur orders Seminar to proceed }\end{array}$ \\
\hline 26 Sept - 18 Nov, 1949 & $\begin{array}{l}\text { The first CCS Management Seminar. It was for top } \\
\text { management only; no substitutes were permitted. The course } \\
\text { ran for } 4 \text { h each day, } 4 \text { days a week for } 8 \text { weeks, with } \\
\text { homework each night. Six sections of the course were devoted } \\
\text { to Quality Control, the largest single topic. As Sarasohn (1997) } \\
\text { relates, there was no final examination at the end of the course. } \\
\text { Rather, participants were told that their success or failure would } \\
\text { be judged by the performance of their companies at the end of } \\
12 \text { months. The list of participants included Takeo Kato from } \\
\text { Mitsubishi Electric, Hanzou Omi from Fujitsu, and similar top } \\
\text { executives from Furukawa, Hitachi, N.E.C. and Toshiba, or } \\
\text { their predecessor companies. }\end{array}$ \\
\hline
\end{tabular}


Table I. Continued.

\begin{tabular}{|c|c|}
\hline Date & Event and people \\
\hline 1949 & $\begin{array}{l}\text { Sarasohn establishes a national electrical testing laboratory to } \\
\text { cater for the entire spectrum of communications products. All } \\
\text { electronic, radio, telephone, telegraph and related equipment } \\
\text { had to be type-tested and quality certified by this laboratory } \\
\text { before being offered to the public. 'If approved, all production } \\
\text { units must then adhere to the same test criteria. To ensure } \\
\text { continuing compliance by the manufacturers, tests would } \\
\text { subsequently be run from time-to-time on items taken at } \\
\text { random from store shelves. If there were any failures, } \\
\text { manufacturers would be required to withdraw all products of } \\
\text { that type until a re-certification test was completed.' [9] The } \\
\text { Electrical Test Laboratory still operates in Japan, fulfilling the } \\
\text { same function set up by Homer Sarasohn in } 1949 \text {. }\end{array}$ \\
\hline Sept 1949 & $\begin{array}{l}\text { JUSE's Quality Control Research Group presents 'Basic course } \\
\text { on the fundamentals of statistical quality control.' }\end{array}$ \\
\hline 21 Nov 1949-20 Jan 1950 & $\begin{array}{l}\text { The second CCS Management Seminar. Participants included } \\
\text { Bunzaemon Inoue from Sumitomo Electric, Masaharu } \\
\text { Matsushita from Matsushita Electric, the top executives from } \\
\text { Sanyo Sharp and (or their predecessor companies). Akio Morita } \\
\text { and Masaru Ibuka, the founders of Sony Corporation, were } \\
\text { schooled separately by Sarasohn [13, Chapter 15] }\end{array}$ \\
\hline 1950 & $\begin{array}{l}\text { Sarasohn invites Walter Shewhart to come to Japan to teach } \\
\text { statistical quality control. Shewhart replies that he is not } \\
\text { available. Sarasohn then arranges for the invitation to be sent to } \\
\text { Deming }\end{array}$ \\
\hline 10-18 Jul 1950 & $\begin{array}{l}\text { Deming visits Japan to teach a course on 'Elementary } \\
\text { Principles of the Statistical Control of Quality' to an audience } \\
\text { of Japanese engineers and technicians } \\
\text { During the course, Deming has dinner with the presidents and } \\
\text { senior officials of some of Japan's leading industries to talk } \\
\text { about Quality. }\end{array}$ \\
\hline 1950 onwards & $\begin{array}{l}\text { CCS Management Seminar eventually taught to over } 5100 \\
\text { people by Japanese themselves. Many return visits by Deming } \\
\text { in subsequent years. }\end{array}$ \\
\hline 1951 & $\begin{array}{l}\text { Joseph Juran's Quality Control Handbook published. Deming } \\
\text { drew the attention of the Japanese to this work }\end{array}$ \\
\hline 1954 & $\begin{array}{l}\text { Joseph Juran's first visit to Japan, invited by JUSE to run } \\
\text { seminars for top and middle management, explaining to them } \\
\text { the roles they had to play in promoting quality }\end{array}$ \\
\hline
\end{tabular}

discussion of control charts. The term 'Cost of Quality' appears here. It is quite evident from the course notes that Sarasohn was concerned with what was later termed 'total quality management' even though the term was coined some years later. Indeed, he had had battles with the Union of Japanese Scientists and Engineers (JUSE) about not teaching statistical quality control until he judged it appropriate:

After the CCS Management Seminars were established and thriving, I wanted to have a specialized, concentrated course on quality control methods specifically for plant managers 
as a follow-on to the quality concepts, philosophy and policy issues I had dwelled on with the senior executives who were my seminar 'students'. I did not want these people to be fixated on the mechanics of statistics. Rather, it was essential that they understand the entire management function and all of its related parts as a SYSTEM, including the component that was statistical analysis. In other words, statistics was merely a tool that is used to gain an ultimate objective. It is not an end in itself. I felt, and feel, strongly on this, and it has put me at odds with some other folks who speak on the subject of Quality Control.

For example, I had to put my foot down unceremoniously with Koyanagi, Koga, Ishikawa and some others of the Japanese Union of Scientists and Engineers (JUSE). They had a simple-minded view. They had come across some early AT\&T reports. It occurred to them that all one had to know was the mathematics of statistics - that was what enabled the United States to win the war!! They saw quality control as an academic exercise. Fortunately, there were others, such as Nishibori and Mabuchi, who were level-headed and wanted not only to learn, but also to understand. Hence, I blocked the JUSE effort to go wandering off on the wrong track. At the same time, I had another motive. I wanted the plant managers' attention to be focused on the production matters at hand. I did not want their concentration diverted to abstractions they were not yet prepared to handle. It was a question of priorities, and JUSE was off-base.

Extracted from a letter from Homer Sarasohn to Lloyd Dobyns, 11 October 1990. See www.honoringhomer.net.

At this point, Sarasohn arranged for an invitation to Walter Shewhart to come to Japan to teach statistical quality control. Shewhart replied that he was not available. Sarasohn then arranged for an invitation to be sent to Deming. Shortly thereafter, Protzman returned to the U.S., and Sarasohn accompanied MacArthur who was being transferred to Korea to cope with the invasion from the north. Outside Japan, there appears to have been little or no awareness of their contributions for some decades (Appendix C, Item 3).

Deming duly arrived to present his course on 'Elementary Principles of the Statistical Control of Quality' [14] to an audience of Japanese engineers and technicians during 10-18 July 1950. It was during this visit that Deming had dinner with a group of presidents and senior officials of some of Japan's leading industries to talk about quality [15, Chapter 1]. This was the first of many visits during which he conducted courses for top management. He arranged for the fees from the courses to be given to JUSE, who used the funds to establish the Deming Prize.

Meanwhile, Joseph Juran's Quality Control Handbook [16] was first published in 1951, and Deming brought it to the attention of the Japanese in 1952. Subsequently, Juran made his first visit in 1954, invited by JUSE to run seminars for top and middle management, explaining to them the roles they had to play in promoting quality.

It is not our purpose to describe in detail all that happened in Japan following these first few years. Other American consultants visited to transfer knowledge and skills. What took place was not so much development in management knowledge but in management knowhow: the practicalities of how to make it all work. A point worth re-emphasizing, and one made repeatedly by Sarasohn, Deming, Juran and others, was that Statistical Quality Control is necessary but not sufficient to sustain provision of quality product and service to customers. SQC can only fulfill its purpose when supported by a broad 'Quality management' culture and approach, led by top management and informing the totality of enterprise activity. 
The developments by the Japanese themselves after 1950 are well known-Quality Circles, application of a core set of tools including check-sheet, control chart, histogram, Ishikawa diagram and scatterplot (see Box et al. [17]), emphasis on incremental improvement; and most notably from a statistical point of view, the work of Genichi Taguchi on parameter design (see below). All of this served to provide a culture of continuous quality improvement suited to Japanese industry. As has been so often the case in Quality Management, the principal advances were introduced by engineers. The Deming Prize became a primary motivating goal for a Japanese company aspiring to excellence.

Parameter design is a framework for quality improvement that was developed by Genichi Taguchi. He had been working on the ideas since the 1950s but they were first introduced to the U.S.A. in 1980 when he visited Bell Laboratories in New Jersey and several other companies. Parameter design was intended as a cost-effective approach for reducing variation in products and processes, designing and developing new products/processes or improving the quality of existing ones. The basic idea in parameter design is to identify the settings of the design (or control) factors that will make the system's performance robust to uncontrollable noise variables while also having the process operate as close as possible to the target value. This is typically done through physical experimentation where the control and noise factors are varied systematically in off-line experiments, and the data are analyzed to identify the settings of the control factors that will achieve robust performance. While the philosophy and engineering rationale underlying parameter design has been widely applauded, the methods for design and analysis that he had proposed have been the subject of controversy. Interested readers are referred to Nair [18]. Nevertheless, Taguchi's ideas found widespread use in North America and elsewhere in the 1980s and 1990s, and there are extensive reports on gains from the use of this approach to variation reduction experiments; see, for example, Phadke [19].

\subsection{Developments elsewhere}

As a prelude to discussing how Quality Management proceeded to evolve elsewhere in the world, we need to emphasize an important point, because it lies at the heart of much confused and ill-informed commentary. Theoretical management, uninformed by practical experience, may well prove difficult to implement-quite analogous, indeed to statistical theory divorced from real experience with data. Actual management experience is a critical prerequisite for a person seeking to create a workable system of management. The striking exception to this was Homer Sarasohn, who created a system - principles, frameworks and plan for implementation - that was successfully put into practice, as evidenced by the success of the companies he established. Deming, however, did not have a background in engineering, had had no experience in line management, and never himself created a system that could be 'operationalized' (see Appendix C, Item 4). The same has been true for many of the people (including many statisticians) who, inspired by Deming's teaching of his Fourteen Principles, proceeded to teach and consult in Quality Management. It explains why much of the writing in Statistics and Quality journals appears so ill-informed when the term 'Total Quality Management' is used, e.g. when TQM is characterized as 'as set of tools', or 'any company-wide plan to systematically boost the quality of their product'; or when Six Sigma is touted as 'the successor to TQM' (cf. Appendix C, Item 5). For example, Banks [20] observes that 'There is nothing deep about TQM', 'TQM strikes many of us as something between a foolish fad and much ado about something trivial', and 'TQM has staggeringly simple ideas. Their connection to statistics is generally slight'. 
The concepts of Six Sigma began life in Motorola in 1987 in response to a pressing business need (its origins are discussed in the following section) and emerged as a commercial package in North America in the mid-90s. It is described by Hahn et al. [21] as a 'highly disciplined and statistically based approach for removing defects from products, processes and transactions'. The term 'Six Sigma' derives from the original goal of having no more than ' 3.4 defects per million opportunities' in products, processes or service operations. The formal statistical formulation is as follows: Suppose you have a process variable that is normally distributed with some mean and standard deviation. Further, suppose the process mean can drift over time within 1.5 standard deviations. Then, if the process is within 'Six Sigma' limits, one will get no more than 3.4 defects per million parts, operations, etc. The proponents note that the formal technical definition is unimportant. What makes Six Sigma work, they assert, is the disciplined, quantitative approach to project selection and improvement.

There are five stages in the approach: design, measure, analyze, improve, and control (DMAIC). These involve: (1) defining the problem to be addressed and the benefits; (2) identifying the socalled critical-to-quality characteristics (CTQs; cf. Appendix C, Item 6), assessing measurement capability, and setting goals for improvement; (3) analyzing and understanding root causes of how defects occur and determining important process variables that cause defects; (4) improving the process by quantifying the effects of the process variables on the CTQs and modifying them appropriately to reduce defects; and (5) controlling the new process to ensure that the improvements are sustained.

There have been reports (see [21]) of billion dollar gains from the use of Six Sigma methods in Motorola, Allied Signal and General Electric (GE). Six Sigma methods have also been adapted from their original applications in manufacturing to improving product and process design (design for Six Sigma or DFSS), design for Reliability and so on. These methods are also being used in service industries in GE, Bank of America and other places; see e.g. van den Heuvel et al. [22] for a report on a successful study in the health care industry. A lot has been written on the origins of Six Sigma, the actual process, its evolution and impact in industry (e.g. [21, 23, 24]).

However, Six Sigma is not 'a successor to TQM' in any sense of replacing Total Quality Management. As recognized by all leading management thinkers from Homer Sarasohn onwards, there is more to Quality than statistical technologies (such as Statistical Process Control) and problem-solving approaches (even those as comprehensive as Six Sigma). By a Total Quality Management system we mean a system — principles, frameworks and a plan for implementationfor how to manage an enterprise, where the Quality principles are, by and large, well understood and accepted by now, but the frameworks and methods of implementation may well vary, especially with the passage of time. Norbert Vogel, one of the most knowledgeable and experienced Quality practitioners, put things into context when he wrote (Vogel [25, p. 70]):

There is a wide variation in perceptions of Total Quality Management (TQM).

It seems that the use of the TQM label has, in itself, given rise to many different interpretations of what it actually means.

For some, it is a management system which is entirely based upon the philosophies and teachings of one of a number of people recognized as pioneers in the Quality Movement. The valuable contribution made by eminent people, including Sarasohn, Shewhart, Deming, Feigenbaum, Ishikawa, Juran (just to name a few) cannot be disputed. However, it is important to understand that there are some fundamental differences in the various philosophies put forward. There are also differences in terms of scope, emphasis and terminology. 
Our understanding of leading edge Quality Management can only be enhanced if we recognize the combined contribution made by pioneers in this field.

There is also a need to maintain access to new research and developments in this broad field and to continually build upon the foundations which underpin TQM. New knowledge is being generated at an alarming rate and it is therefore not appropriate to align TQM in a static way with only one set of theories and methods. [Emphasis added.]

The promotion of a wide range of different packaged versions of TQM has certainly contributed to the confusion. It has also prompted the introduction of new acronyms and prescriptive methodologies as a better alternative to TQM. (Hence such statements as 'TQM was for the $80 \mathrm{~s}$ - the $90 \mathrm{~s}$ is the era of Value-Added Management', 'Total Quality Service', etc.) The fact is that TQM in its broadest sense examines all aspects of management and the alternative methodologies being promoted are merely sub-sets of what should be an integrated management system.

However, there appears to have been little advance in the understanding or thinking of most statisticians about TQM since 1993. Bisgaard and De Mast ([26], e.g. 'TQM largely measured success in terms of activities') exemplifies the prevailing level of understanding and misunderstanding.

In the West, explicit public focus on 'Quality Management' did not occur until the famous June 1980 NBC News report 'If Japan Can ... Why Can’t We?' that featured W Edwards Deming, William Conway and reporter Lloyd Dobyns. Juran had continued with courses, lectures and consulting; Deming was consulting privately; Philip Crosby was developing a successful consultancy based on the thesis that 'Quality is free' and totally omitting, at least in the early days of his work, any reference to Statistics; Armand Feigenbaum consulting on Quality Control; and so on. However, the 1980 report created a watershed in the attention being paid by American companies to Quality Management. Quality Management consultants blossomed, companies started defining Quality in terms of Customers, and understanding and meeting customer needs became a major step towards business success. The increasing use of Standards such as ISO9000 also played a role in forcing suppliers to improve their processes, document their practices and enhance their measurement capabilities. In the late 1980s, Quality Awards had been created in a few countries; for example, the Malcolm Baldrige National Quality Award in the U.S.A. in 1987, created by an Act of Congress; and the Australian Quality Award in 1988, emerging largely from initiatives by business and industry (see Appendix C, Item 7). A Quality Prize established in Northern Ireland was developed in line with the Baldrige criteria. Myron Tribus' account of the historical origin of the Baldrige Award can be found at Tribus [27]. Tribus' thinking about practical expression of Quality principles may well have been the inspiration for the formulation of assessment criteria for both the Baldrige and the Australian Quality Awards.

By the 1990s, it was not sufficient simply to 'meet customer needs': an increasingly competitive business environment meant that companies now had to deliver 'superior value' to customers. 'Quality Awards' were replaced by 'Business Excellence Awards', with a clear focus on Business Results (i.e. outcomes or impact, which had been lacking from the initial type of Awards framework: see Appendix C, Item 8) and the framework now comprised enabling categories such as

1. Leadership and Innovation.

2. Strategy and Planning Processes.

3. Data, Information and Knowledge.

4. People.

Copyright (C) 2009 John Wiley \& Sons, Ltd.

Appl. Stochastic Models Bus. Ind. 2009; 25:1-28

DOI: $10.1002 / \mathrm{asmb}$ 
5. Customer and Market Focus.

6. Processes, Products and Services.

Statisticians had relatively little involvement with the development of these recognition processes. Of course, assessment of a company's performance against categories (3) and (6) necessarily involved seeing how they acquired, analyzed, interpreted and presented statistical data and information ('statistical quality control', in the old language). However, statisticians were slow to respond to one particular aspect of Quality Management: what sorts of measures should an enterprise use to manage itself? Once again, a fundamentally statistical question was raised and addressed first by others. In our view, this is the next major step for Quality Management: developing system(s) for performance measurement.

As a very simple analogy, think about what happens during a medical check-up. The physician collects a few basic measurements-weight, temperature, pulse, blood pressure and a few otherson the basis of which (s)he proceeds to provide advice about

- your current state of health,

- what will happen to your health if you continue your present life style and

- what you need to focus on to improve things.

Add to this some aspects of your financial viability (from the physician's viewpoint, this simply reduces to: have you got medical insurance?) and you have a concise set of performance metrics that capture most aspects of your health. The last bullet point relates to linking the measurements to priorities for process improvement.

The goal is the same for an enterprise: at each level of management, provide concise quantitative reports that assist management in doing their jobs well. Thus, such a system should provide three vital outcomes, as shown in Table II.

The current situation is not very good, especially at Board level. Monthly Board reports frequently comprise little more than financial statements - and even that provided in tabular form, rather than supported by trend charts and other well-chosen graphics-and little else, to assist management of risk.

Sound statistical thinking is critical to achieving this goal. It appears in a variety of ways:

- appreciating the difference between lead and lag indicators, for example, measurement of an output compared with measurement of an outcome, or an in-process measure as a predictor of a Critical-to-Quality metric for a process,

- appreciating that 'measurement drives behaviour' (Appendix C, Item 10) and so being able to select meaningful measures (e.g. at a call centre, 'Percentage of enquiries handled on

Table II. Suggested critical outcomes of a performance measurement system for an enterprise.

\begin{tabular}{ll}
\hline A & For Boards: a quantitative basis for managing Risk (operational risk, risk of a \\
& powerful competitor emerging, risk of losing market share, risk of losing key \\
& staff, risk of losing community support for a key activity, risk of losing a \\
& partnership, etc.) \\
& For leadership teams: a means of selecting improvement activities likely to have \\
the most beneficial impact on the business \\
C & For people working in the enterprise: a basis for monitoring, controlling \\
& and improving processes that aligns with internal and external customer \\
& requirements (cf. Appendix C, Item 9)
\end{tabular}


initial call' rather than measures of activity such as 'number of calls answered per hour') that encourage good behaviours

- ensuring that meaningful data are gathered-defining an appropriate population, devising a suitable design, addressing the sampling aspects, assuring integrity of data capture and storage

- appreciating

$\circ$ the different types of quantitative data, from ordered categorical through to continuous data

$\circ$ how to summarize and analyze them

- how to present the results in an appropriate fashion, particularly with good-practice statistical graphics (trend charts, dot plots, box plots, etc., but not divided bar charts and pie charts), and with appropriate quantification of uncertainty

- understanding how to interpret, explain and manage risk in all its manifestations, whether it be quantifying the uncertainty in a forecast, or assessing the possibility of failure for a complex facility, or interpreting fluctuations in consumer market preferences

- seeking to improve business performance through system and process improvements, etc.

This is what statisticians are equipped uniquely to do. This sort of thinking permeates the rest of the discussion.

\section{THE NEXT STEP-MEASUREMENT-BASED QUALITY MANAGEMENT?}

To provide a suitable setting for discussion, we return to Sarasohn's discussion of organization. He starts with a fundamental concept:

\section{Zones of Management}

There are, in an efficient company, various zones or levels of management which are separate and distinct. Each can be identified by the nature of the functions and responsibilities. The possibility of effectiveness can be measured by the extent to which functions are defined, authority is specified, and accountability is actually required ...

Sarasohn \& Protzman [12].

In modern parlance, these are described as the Strategic, Tactical and Operational Zones, corresponding to the groups of people referred to in Table II. The question addressed in this section is: what measures are needed in each Zone?

In fact, there are three qualitatively different approaches in current use for selecting performance measures.

Approach 1: Using a 'Gold Metric'. Here, the idea is to look for a generic metric that can be used throughout an organization or, equivalently, at all scales of measurement from micro to macro. The power of this concept is that it could be used to focus on communication at all levels of the organization: in the words used by a senior industry figure to one of the authors, 'I want to be able to drill down through management layers with a single metric, to find out what's causing a problem'. The best example of this, or at least, of a pair of such metrics, is provided by the approach to measurement adopted by Motorola in the late 1970s. As described by Debby King-Rowley, who was formerly global Director of Executive Education at Motorola,

There was a very early focus on cycle time reduction across the board. That was introduced from the C-suite down in 1986. At that time, Motorola was working on quality through 
the 3 leading guru schools of thought at the time - Deming, Phil Cosby, and Juran. No single approach was being promoted from corporate. When cycle time was introduced, it was introduced as part of a 3-legged stool - cycle time, quality, cost. All three had to be in balance within the business units. Cycle time was the only one being driven (in goal of 50\% reduction and process) from headquarters. Once cycle time focus was in place, an eye was turned to quality to standardize the approach on a company-wide basis. A lot of work was being done with Deming's concepts, but an internal electrical engineer, Bill Smith, in our then 'Communications Sector' created the concept of Six Sigma. He took the idea to Bob Galvin, who is quoted as telling Bill 'I don't fully understand it, but it seems to make sense. Come meet with me weekly til I understand it.' Bill did, Bob fully grasped it, then others (particularly statisticians like Mikel Harry) were brought in to support and advance Bill's Six Sigma. Then the rest is history.

(Email communication from Debby King-Rowley to NIF, 13 September 2008)

Another version of the 'Generic Metric' approach is advocated by Eliyahu Goldratt, according to whom there are three key performance measurements to evaluate: throughput, inventory and operating expense. There are rather closely aligned with a manufacturing setting. They are also consistent with Goldratt's view that the goal of any company whose shares are traded in the open market is to use invested money to make more money now and in the future [28]. The contrast with Sarasohn's view could not be more striking [5, pp vii-viii], from which we extract a brief quote from a rather more complete argument:

... There is another fault that I would find in such a statement. It is entirely selfish and onesided. It ignores entirely the sociologic aspects that should be a part of a company's thinking. The business enterprise must be founded upon a sense of responsibility to the public and to its employees. Service to its customers, the wellbeing of its employees, good citizenship in the communities in which it operates - these are cardinal principles fundamental to any business. They provide the platform upon which a profitable company is built.

The founder of the Newport News Shipbuilding and Dry Dock Company, when he was starting his company many years ago, wrote down his idea of the objective-the purpose-of the enterprise.

He put it this way. 'We shall build good ships here; at a profit if we can-at a loss if we must-but, always good ships.'

This is the guiding principle of this company and its fundamental policy. And it is a good one too because in a very few words it tells the whole reason for the existence of the enterprise. And yet inherent in these few words there is a wealth of meaning. The determination to put quality ahead of profit. A promise to stay in business in spite of adversity. A determination to find the best production methods.

These two examples highlight the fact that the search for a single generic measure is almost certainly going to be fruitless; and once more measures are included, the whole rationale of the approach is lost.

Approach 2: The Balanced Scorecard. The Balanced Scorecard (e.g. Kaplan and Norton [29-31]) was originally devised as a means of measuring strategy. The authors introduced it as follows:

During a year-long research project with 12 companies at the leading edge of performance measurement, we devised a 'balanced scorecard' - a set of measures that gives top managers a fast but a comprehensive view of the business. The balanced scorecard includes financial 
measures that tell the results of actions already taken. And it complements the financial measures with operational measures on customer satisfaction, internal processes, and the organization's innovation and improvement activities- operational measures that are the drivers of future financial performance.

Think of the balanced scorecard as the dials and indicators in an airplane cockpit. For the complex task of navigating and flying an airplane, pilots need detailed information about many aspects of the flight. They need information on fuel, air speed, altitude, bearing, destination, and other indicators that summarize the current and predicted environment. Reliance on one instrument can be fatal. Similarly, the complexity of managing an organization today requires that managers be able to view performance in several areas simultaneously. The balanced scorecard allows managers to look at the business from four important perspectives.

It provides answers to four basic questions:

- How do customers see us? (customer perspective)

- What must we excel at? (internal perspective)

- Can we continue to improve and create value? (innovation and learning perspective)

- How do we look to shareholders? (financial perspective)

While giving senior managers information from four different perspectives, the balanced scorecard minimizes information overload by limiting the number of measures used. [Emphasis added]

(Kaplan \& Norton [32])

At the time, there was nothing extant to provide specific guidance to organizations about the sorts of measures they should use for management purposes, and the Balanced Scorecard became widely promoted as a response to this need.

Kaplan and Norton provided, as an exemplar of their methodology, a case study from a semiconductor company that they called ECI (Electronic Circuits Inc.). The ECI Balanced Scorecard is shown in Table III. We shall return to this example shortly.

Approach 3: Stakeholder-based approaches. The above quote from Sarasohn and Protzman's Manual [5, pp vii-viii] is interesting for a number of reasons, not least because it clearly identifies four groups with a vested interest in the wellbeing of an enterprise: Owners, Customers, People (i.e. Employees), and the Community. Enterprises are becoming increasingly aware of the need to pay attention to the ongoing needs of each of these groups, and of a fifth group, Strategic Partners (e.g. long-term suppliers). Over two decades ago, Richard Normann, a world-leading strategic thinker in management, formulated the concept of 'adding Value' for stakeholders (e.g. Normann [33]). With 'adding Value' (or outcomes for stakeholders) as the starting point, Dransfield et al. [34] were able to develop a formal structure for organizational performance measures (now known as a Performance Measurement Framework, or PMF ${ }^{\circledR}$; see www.valuemetrics.com.au). This can be represented simply, as shown in Figure 1.

The overall structure has three Zones of Measurement, corresponding to Sarasohn's three Zones of Management. At the top level, the measures are outcomes, or lag measures. At the Tactical level, the measures are outputs, serving as lead indicators of success. At the operational level, the measures relate to day-to-day monitoring, control and improvement of processes that provide products and services to people outside and inside the enterprise.

However, a framework is just one component of what is required. It tells us the sorts of measures that are needed, but not how to obtain them and use them. In fact, a methodology for doing this, 
Table III. ECI's balanced scorecard, as reported by Kaplan and Norton [29].

\begin{tabular}{ll}
\hline Goals & \\
\hline $\begin{array}{l}\text { Financial perspective } \\
\text { Survive }\end{array}$ & Cash flow \\
Succeed & $\begin{array}{l}\text { Quarterly sales growth and operating } \\
\text { income by Division } \\
\text { Increased market share and ROE }\end{array}$ \\
Prosper & \\
Internal business perspective & Manufacturing geometry versus competition \\
Technology capability & Cycle time \\
Manufacturing excellence & Unit cost \\
& Yield \\
Silicon efficiency \\
Design productivity & Engineering efficiency \\
New product introduction & Actual introduction schedule versus plan \\
Customer perspective & \\
New products & Percent of sales from new products \\
Responsive supply & Percent of sales from proprietary products \\
Preferred supplier & On-time delivery (defined by customer) \\
Customer partnership & Share of key accounts' purchases \\
Innovation and learning perspective & Ranking by key accounts \\
Technology leadership & Number of cooperating engineering efforts \\
Manufacturing learning & \\
Product focus & Time to develop next generation \\
Time to market & $\begin{array}{l}\text { Process time to maturity } \\
\text { Percent of products that equal 80\% sales } \\
\text { New product introduction versus competition }\end{array}$ \\
\hline &
\end{tabular}

at least for creating and adding value for Customers, was developed by AT\&T some 20 years ago, when the company was confronted with the paradox of achieving 95\% Customer Satisfaction from its market research surveys and at the same time a $6 \%$ loss in market share (where $1 \%$ equated to \$3.6B). Appendix B contains a brief description of how the Customer Value improvement process works. Its importance in the present context is that

(a) it provides measures in all three Zones of Measurement;

(b) it provides links to higher-level business drivers such as measures of Customer Loyalty and Market Share; and

(c) it links very directly to core business processes and provides guidance about improvement priorities likely to have the most beneficial impact on the business (and so is compatible with a Six Sigma program).

Using the terminology in the Appendix, we can populate Strategic, Tactical and Operational Zones of Measurement with the Customer measures shown in Table IV. AT\&T were able to manage all Customer-related aspects of their business using such Value-based measures.

It is possible to develop analogous approaches to managing value for People, Strategic Partners and for the Community and, ultimately, for the Owners of the enterprise (see www. valuemetrics.com.au for more details). 


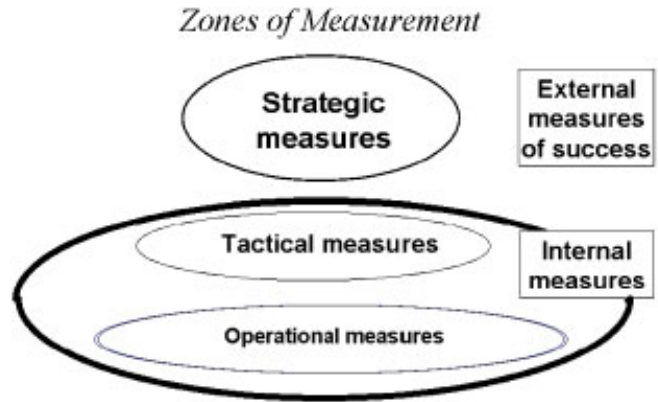

(a)

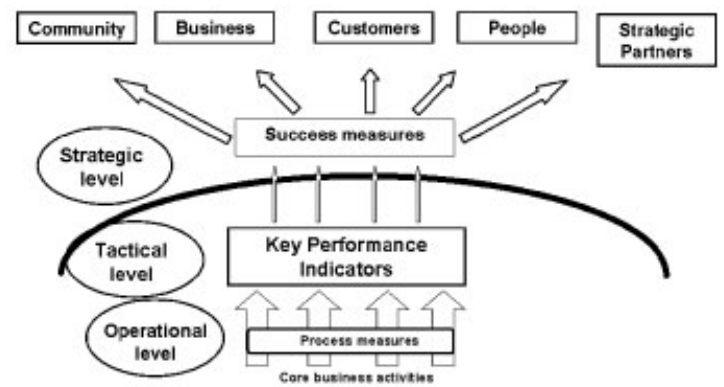

(b)

Figure 1. The performance measurement framework for measures in an enterprise. (a) The overall structure shows three zones of measurement, corresponding to Sarasohn's three zones of management. At the top level, the measures are outcomes, or lag measures. At the Tactical level, the measures are outputs, serving as lead indicators of success. At the operational level, the measures relate to day-to-day monitoring, control and improvement of processes that provide products and services to people outside and inside the enterprise.

Table IV. Example of how a customer value approach provides measures in each zone of measurement.

\begin{tabular}{|c|c|c|}
\hline Zone of measurement & \multicolumn{2}{|c|}{ Value-based measures } \\
\hline \multirow[t]{4}{*}{ Strategic } & Relative satisfaction with quality & \\
\hline & Relative satisfaction with image & \\
\hline & Relative satisfaction with price & \\
\hline & Customer value added & \\
\hline \multirow[t]{4}{*}{ Tactical } & Satisfaction with quality & \\
\hline & Satisfaction with image & \\
\hline & Satisfaction with price & \\
\hline & Value & \\
\hline \multirow[t]{5}{*}{ Operational } & $\begin{array}{l}\text { Process-dependent, e.g. } \\
C T Q s:\end{array}$ & \\
\hline & Accessible & Lead indicators \\
\hline & Responsiveness & Time taken to make contact \\
\hline & Knowledgeable people & Per cent of enquiries handled on first call \\
\hline & Do it the right way the first time & Per cent handled by first point of contact \\
\hline
\end{tabular}

What criteria might one use to evaluate these different approaches as providing a system for measurement of the performance of an organization? Following Dransfield et al. [34], we suggest that a suitable system should satisfy the three requirements in Table V.

It is also reasonable to require that the system be consistent with best management practice criteria, such as McKinsey 7S or the Baldrige framework.

The third approach satisfies all three requirements in Table V. However, such is not the case for Approach 1 or Approach 2.

Approach 1 (Using a 'Generic Metric'), if it is deployed in a Six Sigma program, satisfies Requirement (2) and, to some extent, Requirement (3), but it is basically a methodology for 
Table V. Suggested critical requirements of a performance measurement system for an enterprise.

(1) A concise overview of health of enterprise

- comprehensive

- captures current performance

- predicts likely future performance

(2) A quantitative basis for selecting priorities

- links improvements to business impact

(3) Alignment

- of strategic, tactical and operational measures

- of people's work with organizational intent

implementing process improvement. However, if deployed well, it accords with aspects of best management practice.

The Balanced Scorecard attempts to define the sorts of measures that are required, and goes no further. In other words, it suggests what needs to be measured in four broad categories, but provides no guidance about how to do so. However, the approach does not meet any of the requirements in Table V; nor is it consistent with McKinsey or Baldrige (see Appendix C, Item 11). Some of the difficulties can be seen by revisiting Table III in the light of Table V. (1) Evidently, this example does not provide a comprehensive view of performance. For example, there are no metrics relating to Staff, or the Community, or Strategic Partners. This is a fundamental deficiency long since recognized by many companies that adopt a Balanced Scorecard approach, which are then forced to produce additional scorecards such as an Environmental Scorecard. (2) It provides no real guidance about how to allocate priorities for improvement. (3) There is no recognition of a natural structuring of measures, whether this be the Zone of Measurement hierarchy or lead indicator versus lag indicator (e.g. an internal metric as a predictor for a CTQ). The vast subsequent literature has done little to change the situation, except insofar as recognizing the issue in (A) and producing multiple scorecards as a response.

With this context, where to next?

(a) A number of leading organizations have their own versions of a Performance Measurement Framework in place. However, in our experience and that of various Business Excellence evaluators it is generally the case that the approach to putting performance measures in place is ad hoc, with little or no realization that a common approach to each stakeholder group-whether it be an analogue of the Customer Value Management process or something else-may make sense and simplify understanding throughout the enterprise.

(b) Developing ways of measuring success with particular stakeholder groups provides interesting challenges for statisticians. For example, many companies are being forced to the realization that they need to be doing something, and be seen to be doing something, in what is known as Corporate Social Responsibility-Value Added for the Community, in $\mathrm{PMF}^{\circledR}$ argot. Some indication of how this might be approached in one specific instance (gauging support for research into methods of controlling invasive animals) is described in Fisher et al. [35], but far more work is needed. 
(c) More generally, Boards of companies are focusing increasingly on managing risk across all areas of the company. The sorts of metrics suggested under (b) are a starting point-how well have risks been managed to date? The next, more critical and more difficult step is to select a concise and comprehensive set of Key Performance Indicators (cf. (A) above) that provide prospective information about risk.

(d) It is unlikely that statisticians will be able to make significant progress on the higher-level performance measurement problems until they themselves start to fill leading positions in companies, to develop a proper appreciation of what's needed. Fisher [36] wrote that

The stated purpose of this conference contains the provocative assertion that '[Statistics] does not receive the recognition it needs ... as a vital part of making progress in ... business and industry....'

I agree. I believe that there is a significant divide between senior management in business and industry (Them), and the statisticians (Us) who work on business and industrial problems: in a sense - to borrow from George Bernard Shaw-two groups divided by lack of a common language. A lot of their words aren't in our vocabulary, and a lot of our words aren't in theirs.

Such is not the case in many other major domains of statistical practice-Government, Insurance, Medicine to name but three. Why is this so and what can we do about it in Business and Industry?

We conclude with a point made earlier: actual senior management experience is likely to be a critical prerequisite for a person creating a workable system of performance measurement.

\section{CONCLUDING REMARKS}

(a) Despite the general advances made in Quality Management in the last three decades, the service sector tends to lag well behind, particularly those areas where Six Sigma has yet to make significant headway. Typical of the objections one hears are comments such as:

- 'Quality Management is not relevant to universities'.

- 'You can't manage research'.

- 'Variation' and 'statistical thinking' are only relevant to manufacturing and have no place in service delivery'.

(b) Other basic problems that still exist throughout enterprises relate to (operational) definition, presentation and interpretation of measures. The typical Board report is still characterized by a lack of trend charts and other informative graphical aids, relying instead on tables and the occasional pie chart, and so affording plenty of opportunity to react to point-to-point variation and to set arbitrary numerical targets. The sad likelihood is that this last issue will be confronting statisticians for at least another three decades, as it is best addressed systemically through inculcation of young school children with statistical life skills, and the necessary teaching programs are not yet in place.

(c) Continuing the point in (b), statisticians need to become actively involved now: the need for better Board reporting has never been greater. It is interesting to reflect on how the current failure of the world's financial systems might have been avoided had more attention been paid to managing Risk at Board level, particularly with the aid of good performance measures. 
(d) The whole notion of 'employment' has been transformed since 1980. Many of the current generation of people entering employment appear to have no avowed interest in working for the same employer for more than a few years. It is not unusual to encounter staff turnover rates of the order of $30-50 \%$ per annum. People are also seeking more flexible modes of employment, such as flexible hours, or part-time employment (possibly involving jobsharing) or working remotely. While the principles underpinning best management are still relevant, the way in which they are given operational effect, and the associated language, is long overdue for serious reappraisal. And performance measurement practice will need to keep step.

We leave the final words to Myron Tribus, who wrote, in an article on 'The statistician's stake in the managerial revolution'.

To summarize, statisticians need to become more active in this managerial revolution because, comrades, come the revolution, you will be recognized for your worth and for your ability to contribute. It is in your interest and the interest of your fellow citizens that this revolution succeeds.

(Tribus [37])

\section{APPENDIX A: EXTRACTS FROM THE ANNOUNCEMENT OF THE FIRST INTERNATIONAL CONFERENCE ON BATA SYSTEM OF MANAGEMENT}

The following material appeared in the conference announcement, without further amplification.

\section{TOMAS BATA ON ENTREPRENEURSHIP AND MANAGEMENT}

- Our customer-our master

- Thinking to the people-labor to the machines

- The best quality at the lowest prices

- The best in the world is good enough for us

- Every employee a capitalist

Bata told his workers, 'The next man in line is your customer'-the customer was king and that everything they did was intended for the benefit of customers.

Bata told his managers that they worked for their employee benefit, not themselves-put quality at the head of the list of criteria for management decision making.

Bata introduced profit sharing on a major scale, intending to make every employee rich enough to retire at the age of 55 and start his own business if he wished.

Bata insisted that all relations with suppliers should produce 'win-win' results.

Quick Read on Bata System:

- 'Bata-System of Management,' in: IEBM Handbook on Human Resources Management, Thomson, London, 1998, pp. 359-362.

- Knowledge in Action: The Bata System of Management (First English translation of T. Bata's 'Uvahy a projevy'), IOS Press, Amsterdam, 1992. 
- 'Bata-System of Management: Managerial Excellence Found, Human Systems Management, 7(1988) 3, pp. 213-219.

- 'Three-Man Talk on Bata-System,' (In Japanese) Standardization and Quality Control, 41(1988) 1, pp. 15-24.

During the depression, Bata refused to lay off workers but instead cut the price of his shoes in half and negotiated a $40 \%$ reduction in pay for everyone. His company purchased food and other supplies in wholesale quantities and distributed them to his employees at cost to help them through the hard times.

Bata's shoe output increased at a compound rate of $21 \%$ per annum between 1894 and his death in 1932. The high quality and low cost of his shoes prompted the US shoe industry to petition the US Congress for protection. Similar barriers were erected in other European countries.

At the time the Nazis and Communists set about destroying this capitalistic 'enemy' during the immediate post-war years, the Bata Company had factories and outlets in over 83 countries and outproduced all other shoe companies in the world, combined. The foreign parts of the company exist today, with headquarters in Canada, under the leadership of Bata's son and grandson.

The quality management practices originated by Tomas Bata in the period 1905 to 1932 anticipated in practice what is now called quality management. Current practitioners remain unaware of what Bata did and how it resulted in the greatest shoe-making company the world has ever seen.

(Authorship of these notes is unknown, but they were probably prepared by Myron Tribus, who supplied them to NIF.)

\section{APPENDIX B: THE CUSTOMER VALUE ANALYSIS IMPROVEMENT PROCESS}

The methodology of Customer Value Analysis (CVA) provides a 'best practice' market survey approach to continuously improving the products and services that an enterprise provides to its customers. It was developed originally at AT\&T and has since been documented by one of the principal originators, Ray Kordupleski (Kordupleski and Simpson [38]).

It is, in effect, a continuous improvement cycle that can be represented as in Figure B1.

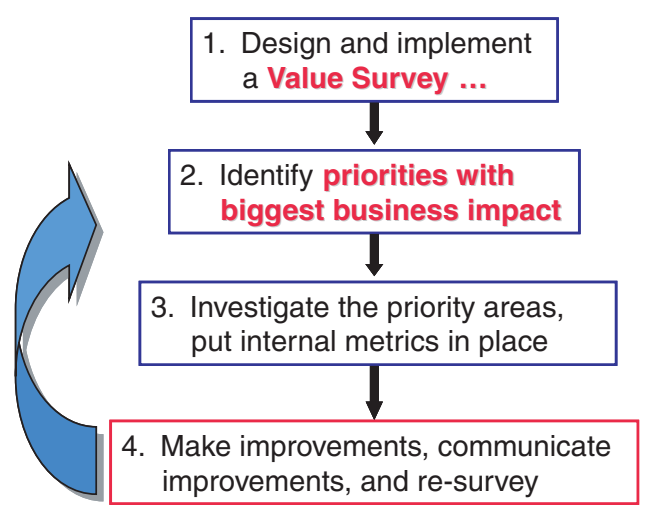

Figure B1. The basic improvement cycle for a customer value survey process. 


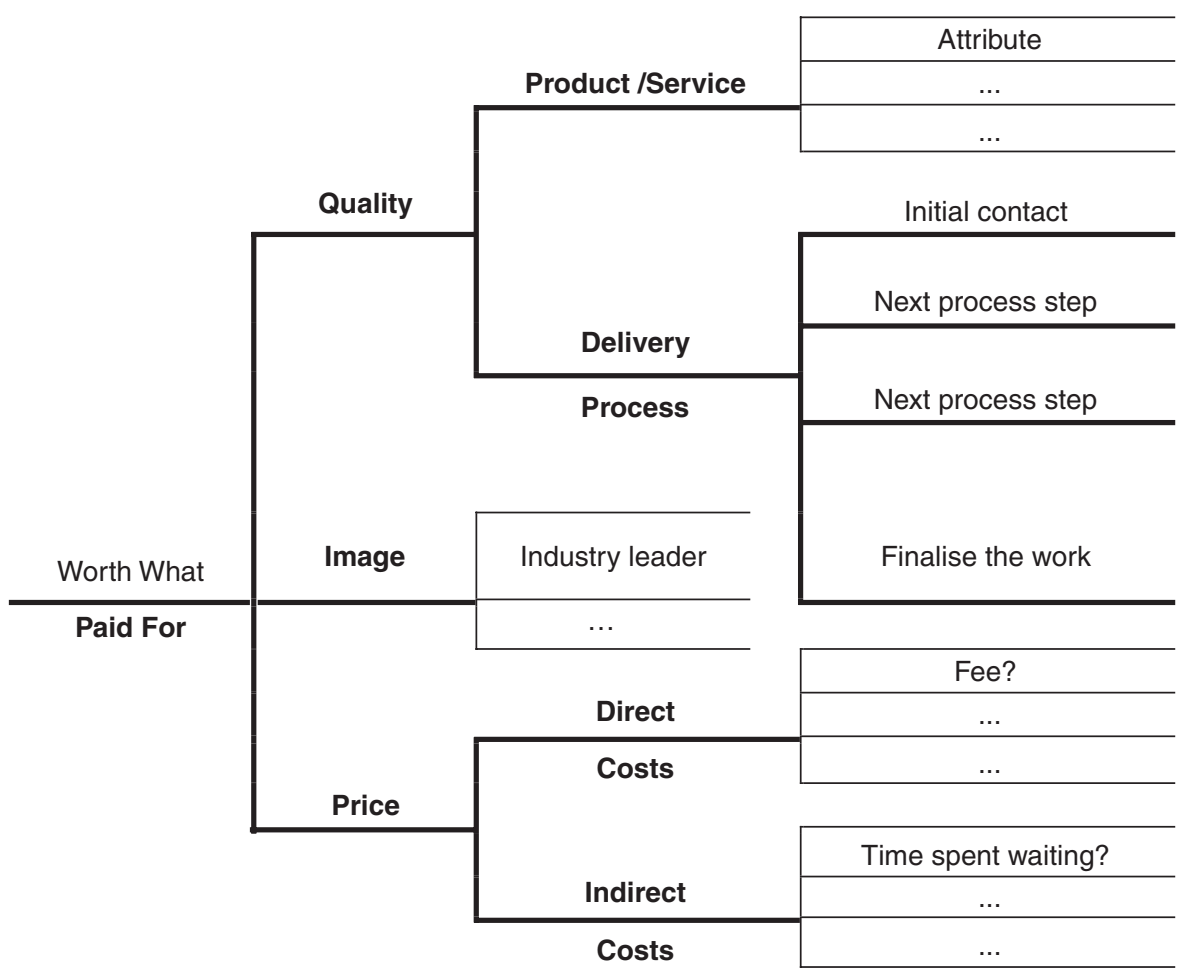

Figure B2. The overall concept of Value is captured by the term 'Worth What Paid For'. In the Customer Value process, the tree structure models Value in terms of three main Drivers, Quality, Image and Price, each of which is modelled by lower-level factors. The lowest-level Attributes are determined from Focus

Groups, so that the survey is customized to fit its target market.

The benefits of the Customer Value approach include:

(a) It is a proven process ... used by leading organizations world-wide

(b) It provides lead indicators for higher-level business drivers

(c) It provides actionable reports for leadership

(d) It helps identify priorities with the biggest impact on the enterprise

The starting point for Customer Value Analysis is a Customer Value Survey. This is based on the concept of a Value Tree, whose basic structure shown in Figure B2.

Focus Groups are used to elicit from the market (customers and prospective customers) which Attributes are most important to them about the product or service being provided (CTQs, in Six Sigma parlance). Then a structured survey instrument is created that focuses on just these Attributes. A survey is developed by asking respondents to rate the organization (on a 10-point scale) on each of the Attributes, and then on all the higher level drivers, until they finally rate Value (Worth What Paid For). This leads to a structured set of scores that can be analyzed using hierarchical regression modelling (e.g. Fisher et al. [39]) to find out which Attributes

- rate lowest, and

- carry the most weight in driving overall Value 
Table BI. Basic presentation of top-level results from a Customer Value survey, showing the relative importance of the three principal drivers of Value (derived from regression analysis), the mean for your enterprise and for your competition, and your performance relative to the competition. Relative scores in bold indicated ratios statistically different from par $(100 \%)$. (RSQ = Relative Satisfaction with Quality, etc.). The term CVA stands for Customer Value Added.

\begin{tabular}{lclll}
\hline & & \multicolumn{2}{c}{ Rating } & \\
\cline { 3 - 4 } & Importance & Your enterprise & Competition & Relative rating (\%) \\
\hline Quality & 46 & $7.2( \pm 0.12)$ & $7.6( \pm 0.13)$ & RSQ $=95$ \\
Image & 10 & $7.5( \pm 0.10)$ & $7.6( \pm 0.10)$ & RSI $=99$ \\
Price & 34 & $6.8( \pm 0.10)$ & $6.6( \pm 0.11)$ & RSP $=103$ \\
Value & $\left(R^{2}=90 \%\right)$ & $7.0( \pm 0.11)$ & $7.3( \pm 0.11)$ & $\mathrm{CVA}=96$ \\
\hline
\end{tabular}

\begin{tabular}{c|l}
\cline { 2 - 2 } Initial & Accessible \\
\cline { 2 - 2 } contact & Responsiveness \\
\cline { 2 - 2 } & Knowledgeable people \\
\cline { 2 - 2 } & $\begin{array}{l}\text { Do it the right way the first } \\
\text { time }\end{array}$ \\
\end{tabular}

Figure B3. Tree structure for a low-level Transaction Survey, after deciding that this is where improvement activity is to be focused. Again, the attributes are derived from Focus Group work. Data are collected in the same way as for a Value survey (ratings on a 10-point scale).

The top-level results are presented as shown in Table BI. From this we can see make a number of important inferences:

(a) Your enterprise is perceived as delivering less Value than your competitors, since the Customer Value Added (CVA) score is significantly les than par (100).

(b) Quality carries more weight than either Image or Price in terms of driving overall Value, and your enterprise is in an inferior position on Quality. Therefore, Quality should be a primary focus for improvement activities, as an improvement of a given amount in Quality will have the biggest impact on Value.

At this stage, the critical next phase of the CVA cycle (which could, for example, be accomplished with a Six Sigma program) commences. Suppose that the process step Initial Contact is identified as a problem. Develop a lower-level Transaction survey, which has a similar but simpler structure than a Value survey. For example, using Focus Groups to identify the quality attributes, the survey instrument could look like the one in Figure B3.

With the CTQs in place, the final step is to identify some internal metrics that can be used as lead indicators to monitor how well things are being done. For example, some possible indicators are shown in Figure B4. These quantities can be monitored with control charts, and cross-correlated to the CTQs.

A typical Value survey also includes Loyalty questions that allow the CVA score to be connected to higher-level business drivers (e.g. Willingness to recommend/repurchase). More generally, there is ample empirical evidence (e.g. Kordupleski \& Simpson, op. cit. Chapter 1) that

- Excellent Value drives Loyalty

- Relative Value (CVA) drives Market Share

- Loyalty \& Relative Value have impact on Return on Invested Capital. 


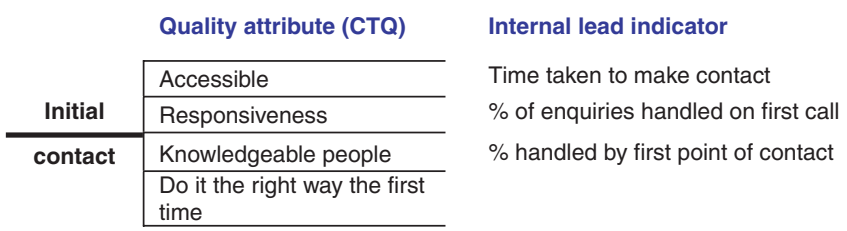

Figure B4. Development of internal metrics that allow monitoring of process improvements. The metrics should act as lead indicators of survey scores for the Quality attributes.

\section{APPENDIX C: NOTES ON THE TEXT}

Item 1. On a visit to the United Kingdom in 1932, Shewhart inspired similar work by B P Dudding, W J Jennett, E S Pearson and others (Keen [40]).

Item 2. Kenneth Hopper and Myron Tribus are the two leading scholars for this topic and era. We have gone into some detail as this material is largely unknown to statisticians and, indeed, to non-statisticians.

Item 3. The reader wondering why the work of Sarasohn and Protzman is not better known may care to consult the article by Robert Chapman Wood [41] on 'A Lesson Learned and a Lesson Forgotten'.

Deming claimed to be completely unaware of the CCS activities until the late 1980s. For example, in the 1986 edition of Out of the Crisis, Deming states: 'The whole word is familiar with the miracle of Japan, and knows that the miracle started off with a concussion [i.e. his visit to Japan] in 1950.' Deming (loc. cit. $p$ 486). The earliest recognition by Deming appears to be in a hand-written note he sent to Kenneth Hopper dated 22 November 1998, in response to Hopper sending him a copy of his 1982 article [42]. The note read:

Dear Mr Hopper,

Your letter and article excite me. I am much indebted to you.

Your article is just what I need.

Sincerely yours

W. Edwards Deming

(Personal communication from Kenneth Hopper to NIF, 9 May 2008)

Around 1990, Deming wrote to Sarasohn acknowledging that there had been activity prior to 1950. (Source: personal communication from Homer Sarasohn to NIF, circa 1999. The letter appears to be lost.) In Architect of Quality: The Autobiography of Dr. Joseph M. Juran [32], Juran wrote

[Deming] came to believe that his 1950 eight-day courses were the dominant reasons for Japan's emergence as the world quality leader. ... These beliefs had no factual support they were wishful thinking. Yet his beliefs were sincere - he believed his wishful thinking. To say that someone believes his wishful thinking is a serious charge, and I am not comfortable with it. Yet there is confirmation in an incident related by Lloyd Dobyns and Clare Crawford-Mason [15]. (They were the creators of the videocast, If Japan Can, Why Can't We?, which propelled Deming into celebrity status.) The incident took place during one of their monthly dinner meetings with Deming. When they pressed him to 
say what had made the difference in Japan, 'Deming drew himself up to his full seated height, slapped his hand on the table, and said firmly and finally, 'One lone man with profound knowledge.' 'It was an absurd, self-serving claim, but in my view Deming was being sincere when he made it.

Item 4. Deming was often quoted as remarking that 'Experience without theory teaches nothing'. Indeed, this is an Index entry in Out of the Crisis (Deming [43]) and one of the four references in the book contains the expanded version 'Experience alone, without theory, teaches management nothing about what to do to improve quality and competitive position, nor how to do it [our emphasis]'. To our way of thinking, this makes no more, or no less sense, than a contrary assertion along the lines 'Theory, without experience, is no aid to making things work in practice.' Both are needed for good management. In his interview with Homer Sarasohn, Myron Tribus comments that he was often approached by people who had attending one of Deming's seminars and then were subsequently confronted with the question 'But how do I get started?'. The first person to take Deming's principles and put them into practice successfully in a Fortune 500 company was William Conway (e.g. Conway [44]), at Nashua Corporation. Sarasohn, Tribus and Conway were all educated as engineers.

Item 5 Other Six Sigma proponents take the same view. For example, Harry \& Schroeder ([45], pp. 10-11), writing about the initial development of Six Sigma at Motorola, proclaim:

'The difference between previous total quality approaches and the Six Sigma concept was a matter of focus. Total quality management programs focus on improvements in individual operations with unrelated processes. The consequence is that with many quality programs ... it takes many years before all the operations within a given process ... are improved ... The Six Sigma architects at Motorola focused on making improvements in all operations within a process, producing results far more rapidly and effectively

As will be seen below, the claims in this passage are either false or misleading. Six Sigma is not a 'total quality' approach, in the sense of Sarasohn, Deming, or Juran (or business excellence frameworks such as Baldrige; see below in this section). It is simply a breakthrough management tool: indeed, this is precisely the assertion of the same authors on page vii of their book!

Item 6 There is a strong link here to the methodology of Customer Value Analysis (CVA); see later. Six Sigma and CVA are mutually supportive technologies.

Item 7 For an interesting account of the origins of the Australian Quality Award in Australia in the late 1970s, see the article 'Creation and Development of the Australian Business Excellence Framework. An Historical Account.' by Norbert Vogel at www.akmgroup.com. This was occurring independently of, and somewhat earlier than, the development of the Malcolm Baldrige National Quality Award in the USA, although there were ongoing contacts between the two sets of developers. Vogel nominates Myron Tribus as the person whose thinking about practical expression of Quality principles was critical to the formulation of both sets of assessment criteria. According to Vogel, 'Agreement was reached on the following outline which provided the basis of a set of criteria against which Award applicants could be evaluated.' The underlying Principles were formulated as:

- All systems exhibit variability,

- High quality does not cost, it pays, 
- People work within a system,

- Everyone serves a customer,

- Improvement efforts should be plan-driven, not event driven,

- Improvement as a way of life,

- To improve the outcome, improve the process.

The operational statements generated under these Principles were grouped under 8 category headings, or Enablers, namely:

- Management Commitment and Leadership

- Policy and Business Plan Deployment

- Customer Orientation

- Relations With Suppliers

- Creative Involvement of People

- Statistical Methods in Management

- Process Control and Improvement

- Communication and Reporting

Item 8 The EFQM (European Foundation for Quality Management) Awards were established in 1992, and so were able to incorporate this improvement. However, it is remarkable that the EFQM has never made any reference to the application of statistical methods or an understanding of variation, presumably because these topics have never been regarded as important in the context of management. (In contrast, the Baldrige and Australian frameworks place high importance on these aspects and associated principles.) It is boggling to contemplate how one might satisfy so basic a Quality precept as the requirement to meet customers' needs without being led inexorably to the issues of process capability and the means of assuring it.

Item 9 Whilst not wishing to make too much of an issue of this, it is worth noting an remark from Norbert Vogel (personal communication) who observed that in some of the early work on developing the Business Excellence frameworks, no real distinction was made between external and internal customers and this was underpinned by one of the original principles: 'everyone serves a customer'. Both Myron Tribus and Yoshikazu Tsuda seriously questioned this and were adamant that the external customer had to be treated quite differently and that satisfaction and perceived value had to be measured in quite different ways. This actually led to the repositioning of the 'internal customer' as a component of managing internal processes and was actually a major shift in thinking at the time.

Item 10 As observed by Eliyahu Goldratt [28] 'You tell me how you measure me, and I will tell you how I will behave'.

Item 11 An analysis by Stan Dransfield of Approaches 2 and 3 in terms of these two sets of criteria can be found at http://www.valuemetrics.com.au/pdf/PMF_versus_BS.pdf.

\section{ACKNOWLEDGEMENTS}

Preparation of this article has been aided immeasurably by Lisa Sarasohn, who made available to us a large number of historical documents from her late father's estate. Ken and Will Hopper, Norbert Vogel, Debby King-Rowley and David Morganstein also provided a variety of helpful material and comment. Feedback from the reviewers resulted in a number of significant improvements.

NIF's research was supported by ValueMetrics Australia. VNN's research was partially supported by NSF-DMS grant 0505535 . 


\section{REFERENCES}

1. Fisher NI, Nair VN. Statistics in business and industry: perspectives on its history and its future. Part II: methodology, applications, and future directions. Applied Stochastic Models in Business and Industry 2009.

2. Juran JM (ed.). A History of Managing for Quality. ASQC Quality Press: Milwaukee, WI, 1995.

3. Fisher NI. Homer Sarasohn and American involvement in the evolution of quality management in Japan, 1945-1950. International Statistical Review 2009; in press.

4. Taylor FW. The Principles of Scientific Management. Harper Bros: New York, 1911.

5. Sarasohn HM, Protzman CB. In The Fundamentals of Industrial Management, Electronic edition, Fisher NI (ed.). Available from: http://deming-network.org/giants_sarasohn.htm.

6. Shewhart WA. In Statistical Method from the Viewpoint of Quality Control, Deming WE (ed.). Dover: New York, Shewhart's original edition first published in 1939 by the Graduate School of the Department of Agriculture, Washington, DC, 1986.

7. Dodge HF, Romig HG. Single sampling and double sampling inspection tables. The Bell System Technical Journal 1941; 20:1-61.

8. Dodge HF. Notes on the evolution of acceptance sampling plans. Journal of Quality Technology 1969; Part I, 1(2):77-88; 1970; Part II, 1(3), 155-162; Part III, 1(4), 225-232; Part IV 2(1), 1-8.

9. Sarasohn HM. Progress through a commitment to quality. National Quality Management Conference, April 1997. Available from: http://www.valuemetrics.com.au/resources001.html.

10. Hopper K, Hopper W. The Puritan Gift. Triumph, Collapse and Revival of an American Dream. I.B. Tauris \& Co Ltd: New York, 2007.

11. Butman J. Juran: A Lifetime of Influence. Wiley: New York, 1997.

12. Sarasohn HM, Protzman CB. The Fundamentals of Industrial Management. Civil Communications Section, GHQ, SCAP, 1948

13. Donkin R. Blood, Sweat and Tears: The Evolution of Work. W. W. Norton \& Company: New York, 2001.

14. Deming WE. Elementary Principles of the Statistical Control of Quality. Nippon Kagaku Gijutsu Remmei (JUSE-Union of Japanese Scientists and Engineers): Tokyo, Japan, 1950.

15. Dobyns L, Clare C-M. Quality or Else: The Revolution in World Business. Mifflin Company: Boston, Houghton, 1991.

16. Juran JM. Quality Control Handbook. McGraw-Hill Book Company: New York, 1951.

17. Box G, Kackar R, Nair V, Shoemaker A, Phadke M, Wu CFJ. Quality Practices in Japan. Quality Progress 1988; 21(3):37-41.

18. Nair VN (ed.). Taguchi's parameter design: a panel discussion. Technometrics 1992; 34:127-161.

19. Phadke MS. Quality Engineering Using Robust Design. Prentice-Hall: Englewood Cliffs, NJ, 1989.

20. Banks D. 'Is industrial statistics out of control?' with discussion. Statistical Science 1993; 8:356-409.

21. Hahn GJ, Hill WJ, Hoerl RW, Zinkgraf SA. The impact of Six Sigma improvement: a glimpse into the future of statistics. The American Statistician 1999; 53(3):208-215.

22. Jaap VH, Bogers AJJC, Does RJMM, van Dijk SL, Berg M. Quality management: does it pay off? Quality Management in Health Care 2006; 15(3):137-149.

23. Harry M. The Vision of Six Sigma, Roadmap for a Breakthrough. Sigma Publishing Company: Phoenix, AZ, 1994.

24. Hahn GJ, Doganaksoy N, Hoerl R. The evolution of Six Sigma. Quality Engineering 2000; 12(3):317-326.

25. Vogel NJ. Integrating quality programmes with the entire organisation. The Quality Magazine 1993; 2:70-74.

26. Bisgaard S, De Mast J. After Six Sigma-what's next? Quality Progress 2006; 39:30-36.

27. Tribus M. Baldrige Origins', 1999. Available from: http://www.baldrigeplus.com/Exhibits/Exhibit\%20-\%20 Baldrige $\% 27 \mathrm{~s} \% 20$ origins.pdf.

28. Goldratt EM. The Haystack Syndrome. Sifting Information Out of the Data Ocean. Croton-on-Hudson Inc., North River Press, Inc.: New York, 1990.

29. Kaplan RS, Norton DP. The balanced scoreboard: measures that drive performance. Harvard Business Review 1992; 70:71-79.

30. Kaplan RS, Norton DP. Using the balanced scoreboard as a strategic management system. Harvard Business Review 1996; 79:75-85.

31. Kaplan RS, Norton DP. Translating Strategy into Action. The Balanced Scoreboard. Harvard Business School Press: Boston, MA, 1996.

32. Juran JM. Architect of Quality: The Autobiography of Dr. Joseph M. Juran. Mc-Graw Hill Book Company: New York, 2003. 
33. Normann R. Service Management: Strategy and Leadership in Service Businesses. Wiley: New York, 1984.

34. Dransfield SB, Fisher NI, Vogel NJ. Using statistics and statistical thinking to improve organisational performance. With discussion and authors' reply. International Statistical Review 1999; 67:99-150.

35. Fisher NI, Cribb JHJ, Peacock AJ. Reading the public mind: a novel approach to improving the adoption of new science and technology. Australian Journal of Experimental Agriculture 2008; 47(11):1-10.

36. Fisher NI. The industrial statistics divide: are statisticians really relevant to business and industry? International Statistical Review 2005; 73:77-180.

37. Tribus M. The statistician's stake in the managerial revolution. Philosophical Transactions of the Royal Society of London, Series A, Mathematical and Physical Science 1989; 327(1596):487-498.

38. Kordupleski R, Simpson J. Mastering Customer Value Management. Pinnaflex Educational Resources, Inc.: Cincinnati, OH, 2002.

39. Fisher NI, Lee AJ, Sparks RS. No more static. Marketing Research (Spring 2005) 2005; 14-19.

40. Keen J. 'Obituary: William Joseph Jennett, 1912-94'. Journal of the Royal Statistical Society, Series A 1996; 159:173-175.

41. Chapman WR. A lesson learned and a lesson forgotten. Forbes Magazine, 6 February 1989; 70-78.

42. Hopper K. Creating Japan's new industrial management: the Americans as teachers. Human Resource Management (Summer 1982) 1982; 13-34.

43. Deming WE. Out of the Crisis. Massachusetts Institute of Technology Center for Advanced Engineering Study, Cambridge, MA, 1986.

44. Conway WE. The Quality Secret: The Right Way to Manage. Conway Quality Inc.: Nashua, NH, 1997.

45. Harry M, Schroeder R. Six Sigma. The Breakthrough Management Strategy Revolutionising the World's Top Corporations. Doubleday: New York, 2000. 